\title{
DO ESCRAVISMO AO CAPITALISMO: O CARÁTER DA DEPENDÊNCIA DURANTE A TRANSIÇÃO (1850-1930)
}

Pedro Pimentel ${ }^{1}$

\begin{abstract}
Resumo
Partindo da noção de escravismo colonial como modo de produção particular à formação sócio-histórica brasileira, objetivamos analisar o caráter da dependência durante a transição ao capitalismo. Neste sentido, observando a definição de Ruy Mauro Marini de que a dependência é uma relação de subordinação econômica entre Estados-nação independentes no plano político, examinaremos os mecanismos pelos quais a sociedade brasileira se "moderniza" na segunda metade do século XIX. Em especial, dois aspectos serão abordados: a expansão da plantagem cafeeira na Província de São Paulo e as primeiras investidas industrialistas na cidade do Rio de Janeiro.
\end{abstract}

Palavras-chave: Escravismo colonial; Capitalismo dependente; Transição; Modernização reflexa; Industrialização.

\begin{abstract}
Starting from the notion of colonial slavery as a particular mode of production to Brazilian socio-historical formation, we aim to analyze the character of dependency during the transition to capitalism. In this sense, observing Ruy Mauro Marini's definition that dependence is a relation of economic subordination between independent nation-states at the political level, we will examine the mechanisms by which Brazilian society "modernizes" itself in the second half of the nineteenth century. In particular, two aspects will be addressed: the expansion of coffee plantations in the Province of São Paulo and the first industrialists in the city of Rio de Janeiro.
\end{abstract}

Keywords: Colonial slavery; Dependent capitalism; Transition; Reflex modernization; industrialization. 1 Mestre em História Social da Cultura pela PUC-Rio. Doutor em Políticas Públicas e Formação
Humana (PPFH-UERJ). Docente no Colégio Pedro II. E-mail: pgp1988@gmail.com. 


\section{Do novo ao antigo caráter da dependência}

Theotonio dos Santos, no ano de 1968, afirmou que para aquele momento "el imperialismo se vuelve hacia el sector manufacturero, se integra a la economía moderna y pasa a dominar el sector capitalista industrial de essas economias" (p. 10). Este era El Nuevo Caracter de la Dependencia, expressão conceitual e histórica que intitulava sua conferência na Segunda Reunião da Assembleia Geral do CLACSO em Lima, no Peru. Tal "caráter" vinha se afirmando enquanto tendências de inversão do capital externo desde o pós-guerras; novo porque marcava a distinção diante da precedente Divisão Internacional do Trabalho, no interior da qual a América Latina fornecia os produtos agrícolas e as matérias-primas para as indústrias dos países centrais e estas provinham os produtos manufaturados.

Inaugurando aquilo que viria a ser conhecido como a Teoria Marxista da Dependência, Dos Santos identificava uma contradição inerente a esse desenvolvimento particular que o capitalismo assumia nos países periféricos, pois, "las condiciones monopólicas en que [las empresas] actúan, limitan sus impulsos orientados a la apertura de nuevos mercados, en economías donde la ampliación del mercado, por la destrucción de los sectores pre-capitalistas o capitalistas atrasados, es el problema fundamental para su desarrollo" (p. 11). Será, contudo, Ruy Mauro Marini, quem examinará, com maior precisão teórico-metodológica essa contradição, classificando-a como uma cisão no ciclo do capital:

O abismo existente entre o nível de vida dos trabalhadores e o dos setores que alimentam a esfera alta da circulação torna inevitável que produtos como automóveis, aparelhos domésticos etc. sejam destinados necessariamente para esta última. Nessa medida, e toda vez que não representam bens que intervenham no consumo dos trabalhadores, o aumento de produtividade induzido pela técnica nesses setores de produção não poderia se traduzir em maiores lucros por meio da elevação da taxa de mais-valia, mas apenas mediante o aumento da massa de valor realizado (2005, p. 177).

Este rompimento nas fases do ciclo do capital, periodizado por Marini como "o novo anel da espiral" é descrito por Mathias Seibel Luce como a emergência da "segunda cisão" (2018, p. 89; pp. 114-119), isto é, um novo momento histórico em que "o divórcio entre as estruturas produtivas e as 
necessidades das massas" (p. 85) têm vez. Sendo esta a segunda cisão que, para Marini, fizera prosperar as correntes desenvolvimentistas da década de 1950, supondo "que os problemas econômicos e sociais que afetavam a formação social latino-americana tivessem origem na insuficiência do desenvolvimento capitalista e que a aceleração deste bastaria para fazê-los desaparecer" (p. 167), devemos delinear a primeira cisão, uma vez que nosso recorte temporal nos remete ao momento de dissolução das relações escravistas de produção no Brasil.

Para Ruy Mauro Marini, na economia latino-americana, "como a circulação se separa da produção e se efetua basicamente no âmbito do mercado externo, o consumo individual do trabalhador não interfere na realização do produto" (p. 164). Essa característica é pertinente ao chamado setor exportador, no qual o café, a banana, o cacau, o cobre, o salitre etc. produzidos ou extraídos no interior dos estados nacionais latino-americanos se destinam a realizar-se na Europa. Assim, a esfera produtiva de maior dinamicidade na composição do produto interno ou da "renda nacional" não tem na sua força de trabalho o ponto de chegada do ciclo. Rompido pela integração subordinada das nossas economias ao mercado mundial (ora hegemonizado pelo capital industrial), as massas trabalhadoras demandam uma produção interna de subsistência ao mesmo tempo em que absorvem a produção industrial através das importações. Este fenômeno prevalece, no Brasil, desde o momento de sua independência política até, pelo menos, as transformações geradas pela Revolução de 1930 e o avanço da industrialização substitutiva.

A ou as cisões no ciclo do capital são uma das leis tendenciais da economia dependente, como afirma, Mathias Luce (2018, p. 231) que, acompanhando a caracterização dada por Ruy Mauro Marini, salienta a distinção entre a "situação colonial e situação de dependência" (p.49). Posto que, em condição de colônia de um Reino, o Brasil, por exemplo, não possa ser considerado como um país, a dependência somente teria lugar quando do estabelecimento de relações de transferência de valor como intercâmbio desigual entre países independentes que, ao se encontrarem no mercado 
internacional, trocam não-equivalentes, perpetuando a reprodução ampliada da dependência, no interior do sistema capitalista mundial. (MARINI, 2005, p. 141)

Essa formulação, apesar de adequada, encontra-se diante de dois obstáculos fundamentais: a) as relações escravistas e semi-servis de trabalho na produção cafeeira e b) o prelúdio industrialista do último quartel do século XIX. A apreciação desses dois entraves poderá contribuir para um maior refino da interpretação de Marini e da validade históricoargumentativa das categorias caras à crítica marxista à dependência.

A integração a um mercado mundial capitalista tem, de acordo com Marini, "como resultado imediato desatar um afã por lucro que se torna tanto mais desenfreado quanto mais atrasado é o modo de produção existente" (p. 155, grifos meus). Assim, "ao se subordinar uma economia escravista ao mercado capitalista mundial, o aprofundamento do escravo é acentuado". Finalmente, "a superexploração do escravo, que prolonga sua jornada de trabalho mais além dos limites fisiológicos admissíveis e redunda necessariamente no esgotamento prematuro, por morte a incapacidade, só pode acontecer, portanto, se é possível repor com facilidade a mão de obra desgastada" (pp. 158-159, grifos nossos).

Está evidente que o uso do termo "superexploração" para caracterizar o aumento da intensidade da exploração do trabalhador escravizado não corresponde à categorização que Marini realizara, páginas antes, para definir o modo como o trabalhador livre assalariado se submetia ao capital nacional como mecanismo de compensação da deterioração dos termos de troca, o intercâmbio desigual. Assim, é importante admitir, como alerta Mathias Luce, o que a superexploração "não é":

Diferentemente do que ocorre com o trabalho escravo, com o trabalho assalariado, e particularmente desde o momento em que se transita para a subsunção real do trabalho ao capital e a lei do valor passar a vigorar plenamente, é possível produzir a desvalorização real da força de trabalho assim como se torna possível também superexplorá-la. Enquanto é impensável ou raro que se pudesse pagar por um lote de escravos abaixo do valor mercantil (este determinado pelo mercado do tráfico de carne humana), com o trabalho assalariado surgem três novidades. Primeiro, o proprietário, ao adotar o trabalho assalariado, libera um custo mais ou menos fixo, antes comprometido com a aquisição de mão de obra escrava. Segundo, passa a contratar a 
mercadoria força de trabalho como capital variável, braços cuja existência pode ser reproduzida e reposta com muito menos dispêndio de capital do que para adquirir e repor plantéis de escravos. Terceiro, o assalariamento reúne uma força combinada de trabalho que poder ser explorada tanto reduzindo seu valor real (obtendo mais-valia relativa) quanto também superexplorandoa (2018, pp. 137-138. Termos grifados no original e passagens grifadas por nós).

As passagens grifadas por nós nos trechos acima citados, tanto os de Marini, quanto o de Luce, indicam que as relações escravistas de trabalho possuem características suficientemente distintas das assalariadas a fim de não considerarmos a economia brasileira como uma economia capitalista. Não é à toa que Marini se refere à "economia escravista" como um "modo de produção atrasado" se comparado com o capitalismo, em sua capacidade de extração e acumulação do excedente produzido. Com efeito, estamos diante de uma problemática que exige uma apreciação teórica congruente, com o intuito de responder, por exemplo, a seguinte questão: sendo impossível transpor limites tais de exploração do trabalhador escravizado, uma vez que o tráfico internacional havia sido abolido em 1850 e a reprodução da força de trabalho escravizada internamente havia se mostrado inoperável, como foi possível estender as relações escravistas até 1888, e aumentar a produção cafeeira com base no mesmo trabalho escravizado, já que não era mais "possível repor com facilidade a mão-de-obra desgastada"?

O que Luce e Marini percebem intuitiva e dedutivamente também fora percebido por outros autores, em especial Ciro Flammarion Cardoso (1979; 1987) e Jacob Gorender (1980), o que os levou, ao reunir mais elementos empíricos da distinção entre as relações escravistas vigentes no Brasil entre os séculos XVI e XIX, e ancorados numa economia política da escravidão, à afirmação da existência de um modo de produção sui generis, o escravismo colonial. Considerando que foi o último autor quem dedicou um abrangente e profundo estudo sobre o escravismo, nos basearemos em suas contribuições para o prosseguimento desta discussão. 


\section{Modernização e reiteração tardia do escravismo colonial}

Mário Maestri enunciou, certa vez, que Jacob Gorender promovera verdadeira "revolução copernicana nas ciências sociais brasileiras" ao propor a tese do "escravismo colonial" como modo de produção particular à nossa formação social, perfazendo quase quatro séculos. Gorender "superava a tradicional apresentação cronológica de cunho historicista do passado do Brasil" ao empreender um "estudo 'estrutural' daquela realidade, para penetrar 'as aparências fenomenais e revelar' sua 'estrutura essencial', isto é, seus elementos e conexões internos e o movimento de suas contradições" (MAESTRI, 2004, p. 9-11). De acordo com Gorender, "o relevante aqui, do ponto de vista teórico, consiste no fato de se compatibilizar um modo de produção baseado na escravidão com a finalidade mercantil. (...) 0 escravismo colonial nasce e se desenvolve com o mercado como sua atmosfera vital (1980, pp. 170-171).

O historiador brasileiro revoluciona o debate ao propor a existência de um modo de produção particular calcado na plantagem e na escravidão, com fins claramente mercantis. Diferenciava-se tanto do feudal quanto do nascente capitalismo pela questão da propriedade dos meios de produção e da terra, pela condição do trabalhador (servo/trabalhador livre/escravo), pela divisão "quantitativa e qualitativa" do trabalho e pela função no mercado internacional. Gorender definiu essas características como "leis tendenciais", paradigma utilizado por Karl Marx em O Capital:

leis 'monomodais', exclusivas do modo de produção escravista colonial, em oposição às leis plurimodais', comum a diversos modos de produção. As leis específicas do escravismo colonial seriam: lei da renda monetária; lei da inversão inicial da aquisição do trabalhador escravizado; leis da rigidez da mão de obra escravizada; lei da correlação entre economia mercantil e economia natural na plantagem escravista e lei da população escravizada (MAESTRI, 2004, p.14).

A contradição do aumento da intensidade do trabalho escravizado e seu consequente esgotamento físico, observada por Marini, é, em realidade, uma das leis tendenciais do escravismo, a lei da população escravizada: 
Se considerarmos uma população escrava de dimensões dadas, verificamos que, ao invés da criação de uma superpopulação relativa, o mecanismo econômico age tendencialmente no sentido da diminuição absoluta da população escrava e da criação de sua escassez. (...) No terço de século em que o escravismo perdurou após a cessação do tráfico africano, (...) a lei da população escrava impôs o reajuste interno do sistema escravista brasileiro, de tal maneira que as regiões de economia decadente passaram a fornecer escravos às regiões de economia florescente. (...) A consequência inevitável não foi senão o fluxo de escravos das regiões menos prósperas ou decadentes em direção à região mais próspera, ou seja, a região cafeeira (GORENDER, 1980, pp. 320325 , grifos nossos).

O que sucede então quando o abolicionismo internacional logra impor o fim do tráfico atlântico de escravizados, a partir de 1850? A reiteração tardia do escravismo em nosso país, num contexto de esgotamento da reposição da força de trabalho - aumento dos preços dos escravizados, ineficácia de reprodução biológica com a realizada nos Estados Unidos, ascensão da luta escrava, abolicionista urbana e das manumissões, isolamento no cenário internacional, promulgação de leis emancipacionistas, etc. - ocorre através de um processo de modernização reflexa da estrutura produtiva, com vistas a redução dos custos de produção e transporte, e a manutenção da propriedade escrava.

Os plantadores de café se viram obrigados tanto a, em médio prazo, criar artificialmente o excedente populacional que pudesse impor uma força de trabalho de reserva - através do projeto imigrantista - quanto a modernizar a estrutura de escoamento da mercadoria, superando as seculares tropas de muares que atravessavam as encostas da Serra do Mar. Em outras palavras, a capacidade de competição internacional do café brasileiro passaria, necessariamente, pela manutenção e ampliação dos rendimentos e pela resolução das contradições de um modo de produção (em vias de desintegração) dependente de outro, ao se encontrarem na realização externa da produção nacional.

A implementação da malha ferroviária talvez seja a mais notória característica da capacidade do capitalismo industrial alterar a composição ecológica das forças produtivas periféricas, em seu próprio benefício, inclusive. 0 fato das "burguesias agrário-exportadoras se relaciona[rem] com o mundo tecnológico moderno $\mathrm{n}[\mathrm{a}]$ função passiva de consumir e não de 
produzir ciência" (DOS SANTOS, 1994, p. 41, grifos nossos.), é definido por Darcy Ribeiro como "modernização reflexa":

Tal ocorre, por exemplo, com a difusão dos produtos da revolução industrial, como instalações de ferroviais ou de portos que "modernizaram" enormes áreas em todo o mundo extra-europeu, apenas para fazê-las mais eficazes como produtoras de certos artigos, mas que, nada obstante, as tornaram importadoras de bens industriais" (RIBEIRO, 1983, p. 56).

Reflexo porque enquanto agente passivo, isto é, que sofre a ação externa da produção industrial, não alcança de forma autônoma a capacidade de produzir tecnologia equiparável às potências centrais. Desse modo, a chegada das ferroviais ao Brasil diz respeito a exportação de capitais, de tecnologias e mesmo de mercadorias; se no país de origem faz parte da produção industrial, aqui pertence ao setor de serviços e ao setor financeiro (juros estatais para cobrir os gastos da instalação e manter a taxa de lucro garantidos pelo Decreto 641/1852), mesmo que favoreça a circulação da mercadoria café (real setor produtivo dominante), reduza seus custos e aumente sua taxa de lucros (MELLO, 1991, pp. 80-82). Em acréscimo, à medida em que as máquinas para a lavoura encontram uma produção tal capaz de ser vantajosa sua exportação - e a acumulação do café permitisse, do lado de cá, sua importação - é o próprio Estado brasileiro que custeia seu traslado e, ao repassá-las para os produtores, fica com a maior despesa. Ao invés de se chocar com o trabalho escravizado, as máquinas do café permitem a expansão da lavoura escravista, ao retirar o trabalhador de tarefas que passam a ser exercidas mecanicamente e o devolvem aos setores do ciclo do café que não foram mecanizados, como a carpa e a colheita.

Contudo, como observado por Luce, "o proprietário, ao adotar o trabalho assalariado, libera um custo mais ou menos fixo, antes comprometido com a aquisição de mão de obra escrava". Isto é, à medida em que o ocaso da escravidão se aproximava cada vez mais no horizonte e os plantadores paulistas promoviam a imigração como forma de atenuar a "falta de braços para a lavoura" - expressão típica da época - e garantir a produtividade, grandes capitais iam sendo aos poucos liberados em favor de uma diversificação da produção. Estamos, pois, diante da lei da inversão 
inicial da aquisição do trabalhador escravizado e sua tendência à desacumulação.

Sendo o trabalhador escravizado, de acordo com Gorender, o "agente subjetivo do trabalho", essa lei é a que elucida a distinção da representação do escravizado no processo de produção escravista e dela decorre as demais leis, principalmente as tocantes ao excedente, à acumulação e à reprodução ampliada. A correta compreensão do mecanismo de participação da força de trabalho na produção desfaz a possibilidade de integrar o trabalhador escravizado na produção capitalista, pois "não é o escravo como tal, como ser humano concreto, com sua força de trabalho concreta, no processo de trabalho concreto, que desempenha o papel de capital fixo [menos ainda como capital-variável], mas o dinheiro aplicado em sua compra se comporta à maneira da forma dinheiro do capital fixo" (GORENDER, 1980, p. 187) Em outras palavras, no capitalismo o trabalhador não é adquirido, mas sua força de trabalho sim:

Se considerarmos a relação capitalista-operário, verificamos que o primeiro só paga o salário depois que o segundo já criou um valor desdobrado em duas partes: o valor equivalente ao salário e a mais-valia (...) no processo diário da produção, antes de receber o salário, o operário criou valores que de imediato, passam a pertencer ao capitalista. 0 adiantamento é feito pelo operário, não pelo capitalista. 0 contrário ocorre com a inversão inicial de aquisição do escravo. (...) Antes de obter dele qualquer produto, já efetuou um adiantamento (pp. 177-178).

Desse modo, "a inversão inicial de compra do escravo não se encarna em nenhum elemento concreto do fundo produtivo do escravista", ou seja, "não funciona como capital". Assim, "o capital-dinheiro aplicado na compra do escravo se transforma em capital esterilizado". Portanto, a recuperação da inversão inicial de aquisição do escravizado "constitui desconto inevitável da renda ou do que se chamaria de lucro do escravista", pois só pode ser recuperada, "à custa do sobre-trabalho do escravo, do seu produto excedente" (pp.188-189. Grifos no original). Por este raciocínio, o preço de compra do escravizado era restituído pelo produto líquido num determinado período, a partir do qual todo o excedente passava a ser lucro. Gorender compara o preço de compra do escravizado ao preço de compra da terra que, enquanto 
não é lavrada, isto é, enquanto não produz, só pode reaver seu custo vendendo-a. Em síntese:

(...) a inversão inicial de aquisição do escravo assegura ao escravista o direito de dispor de uma força de trabalho como sua propriedade permanente e simultaneamente esteriliza o fundo adiantado neste puro ato de aquisição, reposto à custa do excedente a ser criado pelo mesmo escravo (GORENDER, 1990, p. 191).

Desta lei, decorre a problemática da acumulação frente ao excedente criado pelo escravizado. Uma vez que "à análise da lei do excedente não diz respeito o processo de realização do produto comercializável", Jacob Gorender (1980, p. 164) define a parte do "excedente comercializada e transformada em certa quantidade de dinheiro" como renda monetária. De tal excedente, uma parte era reservada ao gasto improdutivo da compra de um novo escravizado, o que, certamente, inibiria a acumulação: no plano macroeconômico, "a importação de escravos constituía uma desacumulação", o que prova "o caráter não somente pré-capitalista, mas também anticapitalista do regime escravista colonial" (p. 211). Entretanto, "a acumulação era possível enquanto os produtos da economia escravista gozassem de preços de monopólio no mercado mundial” (p. 207).

O preço de monopólio era assegurado pelo sistema de "mercados fechados" (p. 506), típico do mercantilismo no qual se beneficiavam tanto a classe dominante colonial, quanto os produtores de manufaturados metropolitanos e ainda os mercadores, responsáveis pela circulação dessas mercadorias. Em ambos os lados se praticava preços excedentes ao valor intrínseco da produção das mercadorias cambiadas. Possuindo os produtos manufaturados valores agregados superiores aos dos produtos coloniais é possível supor que a maior parcela do excedente era capturada pelos produtores metropolitanos e também pelos mercadores que, na maior parte do tempo, funcionavam como um sistema creditício descentralizado.

Para o século XIX, momento no qual os mercados monopólicos deixam de (formalmente) existir, a partir das independências políticas e os subsequentes tratados de livre navegação e comércio, o próprio comércio importador mantém-se enquanto principal captador do excedente, 
"retardando", por sua lógica interna, sua transformação em capital industrial. Esse fenômeno foi percebido por diversos autores e expomos as observações de Wilson Cano que, por sua natureza, se estendem por todo o período em questão:

Apropriando parcelas importantes do excedente gerado em cada região (...) esse capital [acumulado pelas atividades comerciais, P.G.P.] tanto poderia promover a diversificação do investimento local, quanto poderia se constituir em mais um freio a essa diversificação, como se pode pensar das duas hipóteses seguintes.

Se a propriedade desse capital fosse de residentes no exterior, parte do excedente poderia vazar para o estrangeiro, na forma de remessas de lucros, juros, etc.;

Qualquer que fosse a sua propriedade, o "excedente" poderia ser convertido em capital circulante, financiando o aumento dos fluxos de mercadorias provenientes do exterior ou de outras regiões, para o abastecimento local, ao invés de ser transformado em capital industrial (1990, p. 200).

Imaginemos, então, que parte deste capital comercial se interesse em se transformar em capital industrial, ou que apareça condições favoráveis para tal empreendimento, ou ainda que fabricantes nacionais demandem do Estado políticas econômicas que permitam o alavanque de uma indústria dita nacional. Sob que condições e quais aspectos caracterizarão tal transformação?

\section{A "decolagem" da industrialização dependente e a permanência do lucro comercial no ciclo transicional do capital}

Ladislau Dowbor, em A Formação do Capitalismo Dependente Brasileiro, após abordar a dependência colonial e a "modernização da dependência" (p. 95) durante a segunda metade do século XIX, avança sua análise para a "interiorização da relação de dependência", isto é, a "formação de um polo dominante interno". (p. 113) Tal polo seria a combinação de uma "república do café" com o "desenvolvimento da produção introvertida" (p. 132). Assim, a industrialização passaria por duas fases, ambas dependentes: a "decolagem industrial (1850-1889)" (pp.105-109) e a segunda entre 1889 e 1930 (pp.132-139). Acreditamos que Dowbor foi o autor que mais avançou na caracterização das circunstâncias em que se deram a industrialização a partir 
das noções críticas da Teoria Marxista da Dependência ${ }^{2}$. Portanto, partiremos de alguns de seus valiosos apontamentos.

No momento de decolagem, a indústria têxtil brasileira, fazendo uso das máquinas compradas junto aos ingleses, "tende a preencher o vazio deixado por uma indústria que avança e se concentra cada vez mais em produtos que contém um valor incorporado maior" (p. 106). Richard Graham fornece os dados: se no período entre 1850 e 1854, os produtos têxteis participam com 75,55\% das exportações britânicas para o Brasil e os bens de capital perfazem 14,23\%, essa situação modifica-se até atingir, entre 1905 e 1909, 41,79\% para os últimos e 35,88\% para os primeiros (GRAHAM, 1973, p. 330). As exportações da Grã-Bretanha para o Brasil não se reduzem, apenas "deslocam-se: de tecidos de baixa qualidade - e, por conseguinte, de fraco valor incorporado - [para] máquinas e tecidos de luxo" (DOWBOR, idem).

Assim, o Brasil lançava as suas primeiras e modestas empresas industriais com muitas proclamações nacionalistas, mas partia na realidade com uma decolagem que o levava a ocupar os terrenos à medida que iam sendo já abandonados pelo capitalismo dominante. Ao comprar máquinas para satisfazer um mercado que já não interessava à Inglaterra senão de forma marginal, o Brasil permitia ao capitalismo dominante manter a relação neocolonial em dia com o desenvolvimento das suas forças produtivas e renovar as bases técnicas da dependência sem questioná-la (p. 107).

Essa conclusão de Dowbor é certeira no sentido de apontar que o processo - afinal, "substitutivo" de importações - de industrialização opera no interstício de um mercado consumidor já consolidado pela própria dinâmica integrada (e subordinada) da economia plantacionista com o capitalismo central. Denota ainda a racionalidade do fenômeno industrialista brasileiro em se imiscuir num terreno onde a ausência de forte concorrência permite um novo padrão de acumulação. Entretanto, poderíamos ir além, como faz José de Souza Martins, em Conde Matarazzo, o empresário e a empresa, e sugerir que a industrialização "foi uma questão mercantil e o industrial um

\footnotetext{
${ }^{2}$ Apesar de não fazer a justa referência aos conceitos inaugurados por Marini, Dos Santos e Bambirra, Ladislau Dowbor, em diversas, passagens aborda a superexploração como mecanismo de compensação da troca desigual e em outras tangencia a noção de cisão no ciclo do capital (p.141-148) sem, no entanto, desenvolvê-las adequadamente.
} 
mercador" (1976, p. 104). Vale a pena conferir a argumentação de Martins, ainda que extensa:

Para contornar o privilégio de domínio do mercado pelos importadores, nas condições livre-cambistas, necessitava-se o privilégio da proteção contra os preços estrangeiros. Portanto, (...) o empresário industrial encontrava-se ante o dilema de "deslocar" o lucro para a comercialização da mercadoria ou para a sua produção. E as tensões sociais geradas pela última solução tinham que ser "contornadas" pelo recurso a medidas não econômicas e pela exploração das possibilidades socioculturais nesse sentido oferecidas pela situação. A ausência de discriminação entre as implicações do lucro como mais-valia e como lucro comercial explica-se, pois, pelas condições mesmo da industrialização no país, que se deu no bojo do capitalismo comercial interno, segundo a racionalidade deste e não conforme uma racionalidade "própria". Isto é, comerciantes, operários e consumidores apareciam aos olhos dos industriais-comerciantes com o mesmo sentido, por sua vez dado pela situação. Os interesses dos industriais-comerciantes chocavam com os interesses dos comerciantes-importadores. Por isso mesmo, todo o período que vai até 1930 será marcado, no plano da burguesia, pelo debate entre "liberalismo" e "protecionismo", este último como componente da ideologia industrialista que tinha como alvo a expansão da taxa de lucro industrial pela rearticulação do sistema em seu favor (pp. 96-97, grifos nossos).

Dado o valor de síntese dessa argumentação, iremos analisar cuidadosamente as partes por nós destacadas. Em primeiro lugar, é preciso recordar que o parque tecnológico industrial - têxtil, para fixarmos a primeira e mais potente instalação de indústrias - é também importado, assim como eram as mercadorias que irão agora produzir. Isto fazia com que o "deslocamento do lucro para a comercialização da mercadoria ou para a sua produção" não fosse, em si, um "dilema", mas sim a condição de realização desse novo ciclo produtivo, no qual, desta feita, a produção adquire aparência de internalização sem verdadeiramente o fazer, pois alterada a cadeia produtiva é, então, a compra de máquinas - obsoletas para o capitalismo central - que faz a vez da transferência de valor como intercâmbio desigual. Colocado em outros termos, o "empresário industrial" se só configura enquanto "industrial-comerciante", já que impossibilitado até então de concorrer com a produção britânica, ganha espaço exatamente quando se modificam as condições de reprodução do "comerciante-importador", isto é, quando este último compreende que manterá (ou aumentará) seus rendimentos se, ao invés de intermediar a presença da mercadoria final - o tecido - negociar agora as máquinas de sua produção - o tear. 
O que a história da montagem das indústrias têxteis no Rio de Janeiro, confirma, é que, observado o choque de "interesses dos industriaiscomerciantes" com os dos "comerciantes-importadores", são estes últimos que se transformam em "industriais-comerciantes", ou seja, é o capital importador que, mais bem afeiçoado ao mercado interno, se transforma em capital industrial, deslocando-se ele mesmo na posição das etapas produtivas (LEVY, 1994, pp. 95-100). Ademais, a ausência de concorrência interna percebida por Cano ao analisar os dados do censo industrial de 1907 (1990, pp. 201-211), com cada média ou grande indústria têxtil se assenhoreando de um nicho de mercado, soluciona o aparente dilema, mantendo o lucro na comercialização - em lugar da produção - pois, não resolvida a deterioração dos termos de troca e as leis tendenciais do capitalismo dependente, a produção se realiza num mercado de baixíssimo poder de consumo. Isto é, uma vez que a superexploração funciona como mecanismo de compensação do intercâmbio desigual, as indústrias só podem lograr sucesso na comercialização da sua produção se se ativerem a produzir mercadorias que não exijam, do outro lado, um aumento da composição do capital variável, a elevação dos salários.

O caráter dependente da industrialização, então, faz com que não só haja "ausência de discriminação do lucro como mais-valia e como lucro comercial", como inviabiliza, por sua estrutura, a existência mesmo do maisvalor relativo, pela ausência de concorrência e pela própria incapacidade tecnológica ${ }^{3}$. Uma vez que se torna possível produzir a baixo custo, e estipulado um preço mínimo abaixo do qual o comércio importador não poderia vender, a indústria "nacional", ou seja, aquela que realiza sua

\footnotetext{
${ }^{3}$ Cumpre esclarecer que só é possível extrair mais-valor relativo se se reduz o valor real da força de trabalho. Para isto seria necessária uma redução nos custos de produção de benssalariais de modo que o valor da força de trabalho decaia. Uma vez que os bens salariais se compõem de uma produção plantacionista não capitalista no campo ou semi-camponesa nas franjas rururbanas, da produção industrial estrangeira e da produção industrial nacional nascente que opera com o lucro comercial, isto é, precificando acima dos custos de produção, os bens-salariais não tem seu custo (preço) reduzido, impossibilitando contraditoriamente que a indústria nacional reduza o dispêndio de capital variável. Não são a toa as frequentes crises de carestia que assolavam as cidades em todo o período estudado e que serviam de argumento político dos plantadores contra os industrialistas que desejavam o aumento das tarifas de importação para proteger as fábricas nacionais.
} 
produção no âmbito da nação, logra então "vencer" a concorrência externa. Nas palavras de Marini, os fabricantes estariam "burlando" a lei do valor pelo fato de reproduzir internamente o que a indústria central fazia a nível internacional: vender a mercadoria por um preço acima do seu valor (MARINI, 2005, pp. 145-154). Esse mecanismo é tal que, ao permitir a substituição das importações, resulta, então, na operação do lucro comercial em vez do lucro industrial.

Como consequência: "esse início de formação industrial deve ter proporcionado uma taxa média de lucro alta, pelo menos para as grandes e médias empresas modernas, face à quase inexistência de competição que se pode depreender desse quadro" (CANO, 1990, p. 213). Isso nos avaliza sugerir a proeminência do lucro comercial frente ao industrial ou a inviabilidade do mais-valor relativo durante o primeiro estágio de instalação de indústrias de tipo "moderno" enquanto lei tendencial da transição ao capitalismo dependente, ou seja, enquanto mecanismo de compensação de deterioração dos termos de troca ao lado da superexploração da força de trabalho (LUCE, 2018, pp. 100-101; nota 45, p. 101).

Assim, em última análise, a questão das tarifas de proteção à indústria nacional nunca precisou ser verdadeiramente resolvida, como realmente não o foi, já que não havia tarifa que fizesse uma indústria vencer a concorrência externa nos âmbitos do livre comércio sem que se aumentasse exageradamente o custo de vida. Desse modo, a dinâmica inaugurada pela indústria nacional continha em si uma contradição típica do capitalismo dependente. Se o lucro comercial da produção industrial decorre ao mesmo tempo em que se alia à superexploração como compensação do intercâmbio desigual, deve, de forma contraproducente, possuir o consumo como seu próprio fator limitante.

Esta tendência levará a indústria nacional a preencher preferencialmente os ramos produtivos inferiores, isto é, aqueles que requeriam fraco poder de aquisição da massa consumidora. Segundo Dowbor, "um primeiro dado que caracteriza a orientação particular dessa industrialização no início do século é o fato de não se tratar de um 
desenvolvimento paralelo do setor de bens de produção e do setor de bens de consumo" que "encontra-se reforçada em 1920". Apresentando dados dos censos industriais de 1907 e 1920 compilados por Roberto Simonsen, Dowbor informa: $26,7 \%$ e 20,6\% para a indústria alimentar e têxtil, respectivamente, em 1907 e 40,2\% e 27,6\% em 1920 para os mesmos ramos na distribuição setorial da produção (1982, p. 139).

"Os grupos ricos da sociedade brasileira continuavam a comprar tecidos importados, casimiras, seda e lãs para a sua vestimenta", informa Stanley Stein (apud DOWBOR, 1982, p. 142). Assim, “enquanto a esfera 'baixa', em que participam os trabalhadores - que o sistema se esforça por restringir - se baseia na produção interna, a esfera 'alta' da circulação, própria aos não trabalhadores - que é a que o sistema tende a alargar -, se imbrica com a produção externa, através do comércio de importação". (MARINI, 2005, p. 165) Esse fenômeno é categorizado por Ruy Mauro Marini como a transferência de valor, decorrente, de acordo com Luce, da primeira cisão, entre "as esferas do mercado externo e do mercado interno" (2018, p. 90):

O ciclo do capital nesse período foi marcado pela cisão mercado externo e mercado interno. Isto se observa: 1$)$ na origem do investimento $(D-M)$, que provinha das casas comerciais controladas pelo capital estrangeiro e de empréstimos externos; 2 ) nos meios de produção utilizados $(M p)$, que eram em sua grande maioria importados (ferrovias, máquinas a vapor, câmaras frigoríficas, etc.); 3) na força de trabalho ( $F t$ ), que era contratada em condições híbridas entre a subsunção formal e a subsunção real e a baixíssimos salários; 4) na segunda fase da circulação $\left(M^{\prime}-D^{\prime}\right)$ que se dava sobretudo no mercado externo, sem que os trabalhadores cumprissem um papel decisivo na realização das principais mercadorias produzidas, voltadas para a exportação, o que servia de estímulo a que os patrões e o Estado colocassem em marcha o regime de superexploração que estava se configurando, agudizando as relações básicas de distribuição (entre capital e trabalho); 5) na fase de acumulação $\left(D^{1}-D^{2}\right)$, que se completava, geralmente, em circuitos externos à economia dependente; 6) nas relações derivadas de distribuição (entre os distintos setores e frações da classe dominante, local e internacional), em que a riqueza era apropriada sob as relações determinadas pelas transferências de valor [...]" (pp. 93-94, grifos no original).

Interessa-nos, revisando as cinco características observadas pelo historiador, analisar como tal cisão se comporta em relação à dinâmica perpetrada por esse primeiro estágio de industrialização. 
$\mathrm{Na}$ "origem do investimento", devemos acrescentar que, para o caso de muitas indústrias, o capital provinha tanto de acumulação externa quanto interna, isto é, capitais de negociantes nacionais (ou grandes "diversificadores" nacionais) se transferiram da importação para a produção das mesmas mercadorias, mesmo fenômeno ocorrendo com os comerciantes estrangeiros radicados no país. Assim, importava menos os empréstimos externos e mais a permissão da formação de sociedades anônimas sem autorização do Governo, situação destravada a partir da década de 1880 . Quanto aos "meios de produção" se confirma a importação das principais máquinas, quando não se verificava a importação de peças a serem montadas no país, como o caso do fósforo citado por Luz (1977, p.127). Quanto à "força de trabalho" também se repete a contratação em "condições híbridas" como a existência de escravizados na indústria, de posse do empresário ou alugados a terceiros; observa-se também, de acordo com Lobo (1978, p.709716.) a contratação de operários por “empreitada”, por “diária” e, finalmente, por salário mensal. Já na "segunda fase da circulação (M'-D')", desta vez, serão os trabalhadores (em suas diversas formas de recomposição da força de trabalho) que terão "papel decisivo", pois as primeiras indústrias atenderão ao consumo popular.

Importa destacar, concordando com Luce, que a presença dessas indústrias, mesmo sem conferir grande dinamismo às economias latinoamericanas não corresponde à ausência de mercado interno. Para o caso dos escravizados ou colonos era o senhorio que fazia as vezes de comprador. Entretanto, é justo caracterizar essa relação como um fator limitante. Quanto à "fase de acumulação" e "as relações derivadas de distribuição", há uma inversão na ordem de sua reprodução sem alterar profundamente seu padrão dependente: ao invés da mercadoria se realizar externamente à economia nacional, o que garantia lucros para a intermediação comercial final, a realização interna da mercadoria contava com a importação dos meios de produção como elemento que mantinha o intercâmbio desigual. Assim, a acumulação tornava-se compartilhada, porém subordinada internamente, já 
que os industriais pagavam um "tributo" aos produtores de bens de capital, uma vez que tal setor não se desenvolvia no país.

Se, por outro lado, os capitais acumulados quisessem interagir nos ramos produtivos superiores, deveriam enfrentar a concorrência externa, demandando políticas tarifárias compensatórias ou se associar de maneira subordinada ao capital internacional, como ocorrerá nas décadas de 1940 e 1950, internalizando parte do que antes era apenas transferência de valor (na aquisição da maquinaria) e engendrando a segunda cisão no ciclo do capital, como vimos acima. Ademais, está documentado e bem analisado pela historiografia que a indústria brasileira evita também a verdadeira deflagração de um conflito intraclasse ao promover a diversificação de seus investimentos em distintos padrões de acumulação (escravista, industrial, comercial, rentista, usurário ou financeiro): o caso de Francisco de Paula Mayrink que possuía investimentos em estradas de ferro, bancos de crédito, companhia frigorífica, moinho, açúcar, bondes, etc. é exemplar (LEVY, 1994, p. 126).

É desta maneira que podemos entender, com o auxílio de Renato Perissinotto, o surgimento e permanência do "grande capital cafeeiro" como uma fração de classe, na qual o lucro comercial também prevalecia:

(...) embora tivesse uma dimensão produtiva no setor agrário exportador, [o grande capital cafeeiro] ocupava posições privilegiadas em outros investimentos. Essa diversificação fazia com que a valorização cambial não o prejudicasse tanto, pois outras inversões, como as ferrovias, garantiam sua rentabilidade. Nem mesmo a queda dos preços internacionais do café deixava os membros do grande capital em apuros, pois como vimos, na qualidade de proprietários de bancos eles garantiam acesso ao crédito em termos pessoais, tendo, por isso maior resistência à queda dos preços e podendo esperar melhores condições para a venda do produto (1994, p. 47, grifos nossos).

José de Souza Martins apresenta um exame detalhado das relações de produção no cultivo do café após a abolição da escravidão, reivindicando a “compreensão dialética da história da vida social na perspectiva logicamente histórica, que é a multiplicidade dos possíveis e a singularidade das circunstâncias” (p. 11). Desse modo, Martins descarta as interpretações que viam no regime de trabalho baseado nas famílias imigrantes o assalariamento típico do modo de produção capitalista. Por outro lado, 
reconhecendo a vigência da ação do capital, já desvencilhado da inversão direta nos escravizados e assim reproduzindo em escala ampliada a acumulação capitalista, propõe o estudo da "produção capitalista de relações não capitalistas de produção" (passim). Finalmente, conclui pela conceituação de colonato o regime de trabalho a que estiveram submetidos os milhões de imigrantes que se deslocaram à região cafeeira, opondo tanto ao salariato quanto ao escravismo:

No processo capitalista de produção, a mais-valia aparece como produto do capital, como valor que se valoriza a si mesmo, porque o salário aparentemente remunera todo o trabalho do trabalhador. No regime de colonato, a ausência do salário, como forma social dominante da relação entre o fazendeiro e o colono, impedia que ambos vivessem integralmente a ficção necessária da igualdade engendrada pela troca aparentemente igual, equivalente, de dinheiro por tempo de trabalho (p. 77).

Cindindo por completo as análises que defendiam a essência capitalista e abolicionista dos cafeicultores do Novo Oeste paulista, ideia à qual também se opunha Gorender (1980, pp. 555-572), a tese de Martins é um marco, ainda pouco explorado em sua inteira capacidade, para os estudos da transição do escravismo para o capitalismo no campo. 0 sociólogo brasileiro descreve certa mudança de mentalidade do fazendeiro no processo produtivo, decorrente da valorização e precificação da terra e da possibilidade de eliminação do trabalho escravizado cada vez mais perto: "o fazendeiro deixou de ser um amansador de gente para se tornar um administrador da riqueza produzida pelo trabalho" (MARTINS, 1978, p. 9). Tal situação "criou as condições da polivalência do empresário que, rapidamente, tomou o capital e não a terra, tampouco o mando sobre seus trabalhadores, como a referência de sua constituição como sujeito social e econômico" (idem). Essa "polivalência" significa, nada mais nada menos, do que a diversificação da aplicação da renda escravista, até então entesourada.

Divergente do capitalismo, que acumula capital, no escravismo, "a acumulação se manifestava, antes de tudo, na acumulação de escravos. Expandir a produção implicava, aqui, em primeiro lugar, o aumento do plantel de escravos". (GORENDER, 1980, p. 545, grifos no original). 
Esta particularidade conduz à acumulação escravista ao entesouramento: "Entesourar constituía prática comum entre senhores de engenho. Escondiam dentro das paredes da casa-grande ou enterravam no chão dinheiro, joias e ouro". Este tesouro estava fora de circulação e deveria se caracterizar no acúmulo de mercadorias que mais custosamente perdessem seu valor para poderem voltar a participar do processo produtivo como capital-dinheiro.

"O aumento incessante do valor, sentencia Marx, objetivo que o entesourador procura atingir conservando seu dinheiro fora da circulação, é atingido pelo capitalista que, mais inteligente, lança sempre o dinheiro de novo em circulação" (2017, p. 229). A lenta, mas insistente transformação da economia brasileira ao longo do século XIX, iria permitir que parte da renda acumulada na plantagem cafeeira pudesse ser reinvestida em outras esferas, prioritariamente comerciais e secundariamente produtivas. Contribui essencialmente para essa circunstância a abertura da estrutura econômica nacional à integração plena (e subordinada) ao comércio internacional após a superação da condição colonial. A renda, não mais entesourada, se deslocaria para a formação de sociedades anônimas propiciadoras de atividades comerciais vinculadas à importação de mercadorias inglesas e paulatinamente à implantação de ferroviais e a instalação das primeiras indústrias têxteis.

Às incertezas da nascente produção industrial a partir da segunda metade dos oitocentos somava-se a resistência dos grandes plantadores em investir nas indústrias de transformação. É peculiar, para os fins desta discussão, observar como a historiografia tratou do assunto. Nicia Vilela Luz afirma que os fazendeiros do Império "preferiam aplicar as suas economias em apólices do governo, amedrontados, como viviam, com a instabilidade de uma economia sujeita a crises frequentes, presa fácil de aventureiros e especuladores". (1975, pp. 38-39). Maria Barbara Levy, por sua vez, destaca que "recebendo em períodos anuais determinados a renda das safras, [os grandes produtores agrícolas] investiam em títulos do governo, dos quais poderiam desfazer-se ao longo do ano, na medida do fluxo dos seus gastos 
correntes" (1994, p. 89). Essa mesma autora, em outra passagem, sustenta que "os títulos de renda fixa do governo eram tão seguros e atraentes para a grande maioria dos investidores, que constituíam um freio natural a operações [na Bolsa de Valores]" (p. 117). Finalmente, alega a existência de "preconceitos de uma sociedade dominada pela agro exportação" (p. 87).

Em que pese as inestimáveis contribuições de Luz e Levy, através das quais nos é possível traçar um resumo histórico das nuances do processo de industrialização verificado no século XIX, sobressai a ausência de uma compreensão mais acurada do que era a economia escravista durante o período de transição, o que as leva a se vincularem aos argumentos dos industrialistas. Neste sentido, ao invés de "preconceitos" e "amedrontamento", subsiste a racionalidade de uma economia não capitalista na qual prevalecia o entesouramento como forma de acumulação. O erigir de um Estado nacional capaz de garantir a rentabilidade de seus títulos da dívida, inclusive durante períodos de crise (LEVY, p. 89), permitira a substituição da salvaguarda de pratarias e outros tesouros - típicos de período colonial - pelo investimento seguro nas apólices do governo, sem no entanto, evitar que os plantadores continuassem a entesourar.

Contraditoriamente, esse "investimento" transitava de um tipo de acumulação a outro. Durante a Guerra do Paraguai, 28\% das despesas do Estado (do total de 614 mil contos de réis) serão provenientes desses mesmos títulos (PELÁEZ \& SUZIGAN apud LEVY, 1994, p. 91). É demasiadamente conhecido o surto industrial interno provocado pela Guerra:

A abundância interna da matéria-prima [algodão], somada às encomendas do Exército, fizeram crescer a indústria têxtil do algodão. Foi estimulada também a produção de calçados, de alimentos e bebidas, e de vários outros setores como o de produtos químicos e de vidros, construção naval, produtos óticos, curtumes, chapéus, cigarros e papel. As fundições beneficiaram-se não só pela guerra, mas também pelo progresso agrícola e pela construção de estradas de ferro. Até as antigas fábricas de ferro-gusa foram reativadas (p.94).

Além do fomento proporcionado por uma "economia de guerra", a necessidade de modernização da infraestrutura de transporte e escoamento da produção plantacionista também favorecia a transição, ainda que 
compartilhando subsidiariamente a acumulação com o capital internacional. Este é o caso da diversificação dos investimentos dos fazendeiros na implantação das ferrovias já discutidas acima, mas também do papel que o Estado, enquanto agente modernizador, irá exercer na instalação de serviços de urbanização e comércio durante o período a que nos dedicamos.

Isto nos leva a tratar do ciclo transicional do capital como processo fundamental de expressão da transição do escravismo para o capitalismo dependente. Merece atenção o uso do termo transicional no lugar de transitório. Enquanto "transitório" diz respeito à efemeridade de certos processos, que por razões as mais variadas tendem a durar pouco tempo, preferimos a utilização de "transicional" por caracterizar a passagem de um estado de coisas a outro que, assim completada, altera seu caráter fenomênico. No nosso caso, abordamos a passagem de um modo de produção a outro. Esta passagem, compreende um período que, não importando $a$ priori sua durabilidade, assinala profundas transformações na economia brasileira que, realizado seu percurso, tornaria o capitalismo dependente como modo hegemônico da formação social, substituindo o escravismo por seu completo aniquilamento.

Em linhas gerais, apontamos algumas características deste ciclo.

A modernização reflexa ou dependente beneficiou tanto o setor agrário quanto o industrial, em diversos aspectos, inclusive o creditício e o financeiro. Ao invés de se oporem, necessariamente, a evolução combinada dos setores durante muito tempo classificados como "atrasados" e "modernos", permitiu o crescimento de ambos, ainda que se tenha como verdade que o setor urbano-industrial seja dotado de maior capacidade de diversificação, competição e acumulação. Assim, o desenvolvimento urbano do século XIX, fruto da diversificação econômica, da mudança de mentalidade e do aumento da pauperização do campo com o aprofundamento da expropriação do excedente agrário, associado ao crescimento natural e artificial (imigração) da população gerou uma "expropriação originária" que servirá de exército constante de reserva para as nascentes indústrias. 
Compelidos a buscar alternativas ao trabalho escravizado, uma das primeiras investidas feitas pelos plantadores será a criação de companhias imigrantistas. Em outro trabalho, abordamos o "espírito escravista" dos plantadores do Oeste e do Novo Oeste paulista ao apresentar os dados relativos à presença de escravizados versus imigrantes livres nos principais municípios produtores. (PIMENTEL, 2018) É mister retomar esse debate a partir do significado da imigração no ciclo do capital apresentado.

Apesar de revogado em 1890, o Decreto № 2.827, de 15 março de 1879, mais conhecido como "Lei de Locação de Serviços" "providenciava principalmente para que houvesse ordem e regularidade nos serviços contratados, assegurando a manutenção de um nível razoável de produtividade e a recuperação em tempo previsto dos investimentos feitos". (LAMOUNIER, 1986, p. 121, grifos nossos). Elaborada para servir também como instrumento de atenuação da revolta dos antigos contratados pelo sistema de parceria, principalmente os estrangeiros, a lei de 1879 objetivava promover uma estrutura jurídica segura para a transição ao trabalho livre, uma vez que se dirigia, inclusive aos trabalhadores nacionais e à prestação de serviços por libertos que a Lei do Ventre Livre já havia proposto. Vejamos mais de perto os meandros da legislação:

A nova lei de locação de serviços surgia então como uma panaceia para todos os males. Ela vinha com o intuito de garantir a estabilidade dos trabalhadores, os baixos salários, e com obrigações (e penalidades respectivas) para o cumprimento de longos contratos, e ainda com precauções contra as greves e paralisações coletivas. (...) Muitas cláusulas que antes constituíram o mote principal das queixas dos contratados foram praticamente reformuladas, como a transferência, a proibição da cobrança de juros sobre o débito inicial do locador, a permissão para o rompimento do contrato no primeiro mês de chegada no Império, a permissão para o casamento fora da freguesia e outras (LAMOUNIER, 1986, pp. 118-120, grifos no original).

O ponto nodal estava na razão de que "enquanto os fazendeiros que se interessassem pela contratação de estrangeiros, tivessem que arcar com o ônus das passagens e despesas, eles cuidariam primeiro de se rodear das garantias necessárias para o bom êxito de seu investimento". (p. 121. grifos nossos) Se o controle sobre greves, a proibição da transferência, do rompimento do contrato e de casamentos fora da freguesia não fossem 
suficientes para interpretar a legislação de transição como regida pela lógica escravista - e não pela capitalista - do ponto de vista da teoria econômica, os longos contratos, juros sobre o débito inicial e a recuperação dos investimentos devem servir de argumentação.

O investimento inicial do fazendeiro - traslado e sustento do imigrante - era um capital esterilizado idêntico à inversão inicial na aquisição do plantel, como admite Martins:

0 trabalhador entra no processo produtivo como renda capitalizada, já que o fazendeiro tinha que custear transporte, alimentação e instalação do colono e sua família. Esse dispêndio podia ser inferior ao preço do escravo, mas alterava em muito pouco a qualidade da relação entre o fazendeiro e o colono. 0 trabalho livre era ainda o trabalho de um trabalhador que continuava assumindo a forma de renda capitalizada do fazendeiro, mediante antecipações de capital aos traficantes de imigrantes. Isso instituía uma modalidade de servidão por dívida do colono em relação à fazenda. 0 que o fazendeiro nele gastava não era salário, era investimento" (2010, p.49).

Impossibilitados jurídica e ideologicamente de obrigar o colono a trabalhar por toda a vida, o fazendeiro necessitava impedi-lo de "dar calote", tornando o capital esterilizado um capital morto. Durante décadas, a experiência da imigração e da colonização para a produção cafeeira fez com que o ciclo do capital escravista permanecesse quase o mesmo. Como capital de transição, uma relação monetária começa a se expandir, de modo que o “D” deveria contar com quantidades mínimas de moedas que seriam dadas ao colono como meio de pagamento, no acerto anual com o fazendeiro.

Assim, a acumulação de "tipo escravista" (propriamente dita ou colonata) persiste até que estejam completamente dissolvidos os compromissos econômicos de reposição do investimento inicial (ou o Estado assuma esse papel, como no caso da imigração subvencionada do já Estado de São Paulo), sendo substituídas por outras formas coercitivas, com fundamentos econômicos de expropriação.

Portanto, se o capital comercial se valoriza a partir da intermediação da produção de "tipo escravista", isto é, financiando, refinanciando e negociando o resultado da produção, o ciclo transicional se mantém ativo: há captações monetárias que se originam da produção em que parte do capital-dinheiro se encontra esterilizado. Simultânea e concorrencialmente, se parte do grande 
capital comercial não possui vínculos com a produção plantacionista (e escravista), se ligando unicamente a indústria estrangeira e a produção manufatureira interna, ele dá origem e retroalimenta o ciclo "típico" do capital capitalista, especialmente na cidade do Rio de Janeiro; esse é o caso do processo substitutivo de importações.

Contudo, à medida que esse capital se encontra com o de "tipo escravista" na mediação bancária ou financeira, perde sua autonomia e retorna ao lento ciclo transicional que tem por "natureza" seu caráter histórico de um período de reorganização dos padrões de reprodução simples e ampliada. 0 caso paulista, sobretudo devido à persistência do colonato, mais uma vez, assim como fizera com a dissolução do escravismo (PIMENTEL, 2018), parece tencionar desfavoravelmente ao encerramento histórico do ciclo. Novamente será a luta de classes, colonos versus fazendeiros que, os primeiros almejando à pequena propriedade privada e à pequena produção cafeeira, irá forçar positivamente para a etapa final da transição, libertando para si próprios - e para o capital - o padrão capitalista de acumulação.

Evidentemente contribui para esse processo o crescimento populacional (artificial e vegetativo) e a própria diversificação da produção para o qual o advento e significativo crescimento da indústria concorre fundamentalmente. Suas razões já foram expostas: a autonomização do padrão - ou do ciclo - capitalista de acumulação, além do fator ideológico provocado pelos horizontes burgueses de enriquecimento a partir do trabalho individual/familiar dedicado e abnegado (MARTINS, 2010; 1976).

Finalmente, defendemos a hipótese de que é a condição de integraçãosubordinação da economia brasileira ao sistema mundial o fator condicionante da longevidade do ciclo transicional e o "retardamento" da industrialização. A isso deve se somar a capacidade política da fração hegemônica das classes dominantes em promover o funcionamento do Estado a seu favor: a manutenção das importações (através da oscilante política tarifária), a desesterilização do capital plantacionista (que permite, 
finalmente, sua diversificação) e a formação do preço do café através das políticas de valorização, como a compra e a queima dos estoques.

\section{A transição dependente}

A leitura de Dialética da Dependência não deixa dúvidas quanto a percepção que Ruy Mauro Marini tinha acerca da imbricação entre relações de produções díspares que, em sua concepção, poderiam resultar em modos de produção "atrasados". Assim, parece-nos razoável insistir que a categoria da dependência tem, em seu cerne, a concretude histórica da emergência de estados nacionais politicamente independentes, livres do jugo colonial. Para Marini, a dependência deve ser "entendida como uma relação de subordinação entre nações formalmente independentes, em cujo marco as relações de produção das nações subordinadas são modificadas ou recriadas para assegurar a reprodução ampliada da dependência" (p. 141).

Isto nos conduz a interpretar a utilização que Gorender faz do termo "dependente" como uma condição sem a qual o escravismo, enquanto modo de produção que tem a realização do seu ciclo produtivo completamente distante das massas trabalhadoras escravizadas, não poderia se reproduzir. Assim, a necessidade da existência de mercados monopólicos é característica de um sistema mundial não capitalista, já que o capital industrial, aquele que se autonomiza ao subordinar realmente o trabalho engendrou um novo sistema mundial, desta vez, o livre-cambista.

A análise das contradições entre o escravismo enquanto modo hegemônico na realidade brasileira durante o século XIX e o modo especificamente capitalista que se afirmava no mercado mundial confirma, contudo, a possibilidade de que tanto o escravismo quanto o nascente capitalismo brasileiro serem, ambos, dependentes. Desta feita, dependente não de um mercado fechado, mas enquanto modo que ao determinar o caráter estrutural da formação socioeconômica, gerou um Estado escravista formalmente independente, porém integrado de forma subordinada à circulação mundial de mercadorias e reprodutor das leis tendenciais da dependência. Quer dizer, um Estado que se endividava para instalar 
ferroviais que liberavam a massa escravizada do transporte do café, permitindo que estas fossem realocadas nos estágios iniciais da produção, reiterando, portanto, o escravismo. Um Estado que titubeava diante de uma política protecionista à indústria nacional para não contrariar os interesses plantacionistas bem como os dos grandes importadores, mas que ao mesmo tempo subsidiava a compra de maquinarias que permitiram a instalação das primeiras indústrias têxteis no Rio de Janeiro.

Acreditamos estar em uma lacuna historiográfica e interpretativa. Por limites óbvios, e já esclarecido por outros autores, o escravismo tem seu destino na Abolição e no soerguimento do Estado burguês (SAES, 1987). Do outro lado, como apontado no item anterior, o conceito de dependência relaciona-se com um recorte político e não vincula, obrigatoriamente, um determinado modo de produção, o capitalismo. Como buscamos originar, a partir dessas duas vertentes, um instrumento de análise para o período que chamamos de transicional entre o escravismo e o capitalismo, nos distinguimos da historiografia que opera a investigação por meio da oposição entre Monarquia e República ou entre trabalho escravizado e trabalho livre. Com efeito, a primeira oposição vincula-se ao nível dos acontecimentos, de uma curta história política na qual o movimento republicano ganha força a partir da década de 1870 e sai vitorioso imediatamente após a abolição. A segunda oposição, aparentemente mais extensa temporalmente, mesmo considerando a coexistência de formas de trabalho livre e escravizada desde os primórdios da colonização, vacila entre a demarcação de datas e fatos que teriam dado primazia definitiva ao trabalho livre - quem dirá ao assalariado.

Motivamo-nos por outra questão. A da transição entre a hegemonia de modos de produção numa dada formação social. Ainda que determinante da estrutura normativa do Estado e dinamizador principal da produção, o escravismo colonial, durante a segunda metade século XIX passa a se confrontar com particularidades inerentes à sua reiteração dependente que associadas à sua verdadeira contradição (a luta dos escravizados pela emancipação definitiva), tendem por derrubá-lo, na emergência do capitalismo. 
Esse processo histórico tem sua proposta de inteligibilidade teórica e analítica na noção de uma transição dependente. Tal conceituação é o amálgama das contribuições da Teoria Marxista da Dependência, de Darcy Ribeiro e de Jacob Gorender. Ela inclui a) a existência do escravismo colonial enquanto modo de produção distinto, porém dependente (a partir de certo momento) do desenvolvimento do capitalismo a nível internacional; b) a emergência do capitalismo na esteira do esgotamento do escravismo e dependente da modernização reflexa sofrida por ambos os modos de produção; c) a noção de revoluções tecnológicas, que distinguem dois processos civilizatórios (o colonial associado ao escravismo e o neocolonial vinculado ao ocaso do escravismo e à emergência dependente do capitalismo), e; d) a decorrente impossibilidade de um desenvolvimento autônomo do capitalismo brasileiro, uma vez que se configura de forma periférica e subalterna ao desenvolvimento dos países centrais, caracterizando leis próprias inerentes à sua dependência.

\section{Referências}

PIMENTEL, Pedro G. "A expansão escravista da plantagem cafeeira e o movimento demográfico na província de São Paulo. 1850-1888”. Revista Brasileira de Geografia Econômica. Ano 7 N.13. Rio de Janeiro, 2018. Disponível em: https://journals.openedition.org/espacoeconomia/3494. Acesso em 29/06/2019.

PIMENTEL, Pedro G. "Modernização e dependência na crise da 'segunda escravidão' no Brasil. In: Anais do XXIV Encontro Nacional de Economia Política. Niterói: Sociedade Brasileira de Economia Política, 2019. Disponível em: https://sep.org.br/anais/2019/SessoesOrdinarias/Sessao2.Mesas11 20/Mesa12/123.pdf. Acesso em 29/06/2019.

CANO, Wilson. Raízes da Concentração Industrial em São Paulo. Coleção Estudos Históricos, N.17. São Paulo: Hucitec, 1990. 3.ed.

CARDOSO, Ciro Flamarion S. Escravo ou Camponês? O protocampesinato negro nas Américas. São Paulo: Editora Brasiliense, 1987.

CARDOSO, Ciro Flamarion S. Agricultura, Escravidão e Capitalismo. Petrópolis: Vozes, 1979. 
DOS SANTOS, Theotonio. "El Nuevo Carácter de la Dependencia". Cuadernos del Centro de Estudios Sociológicos. N.10. pp. 1-25. Disponível em:

http://repositorio.iep.org.pe/bitstream/IEP/1042/1/Dos\%20Santos Nuev o-caracter-dependencia.pdf . Acesso em 28/06/2019;

DOS SANTOS, Theotonio. “Economía mundial Integración regional y desarrollo sustentable: las nuevas tendencias y la integración latinoamericana" In: DEL VALLE RIVERA, Carmen y VILLAZUL, Sergio Javier Jasso (comp.) Obras reunidas de Theotonio Dos Santos [libro electrónico], México, IIE, UNAM, 2015.

DOWBOR, Ladislau. A Formação do Capitalismo Dependente no Brasil. São Paulo: Brasiliense, 1982.

GRAHAM, Richard. Grã-Bretanha e o início da modernização no Brasil. 1850-1914. São Paulo: Editora Brasiliense, 1973.

GORENDER, Jacob. O Escravismo Colonial. Coleção Ensaios, N.29. São Paulo: Editora Ática, 1980. 3.ed.;

LAMOUNIER, Maria L. Formas de Transição da Escravidão ao Trabalho Livre: a Lei de Locação de Serviços de 1879. (Dissertação de Mestrado). Instituto de Filosofia e Ciências Humanas, UNICAMP. Campinas: 1986.

LEVY, Maria Bárbara. A Indústria do Rio de Janeiro Através de Suas Sociedades Anônimas: esboços de história empresarial. Rio de Janeiro: EdUFRJ/Prefeitura da Cidade do Rio de Janeiro, 1994.

LOBO, Eulália M. L. História do Rio de Janeiro (do capital comercial ao capital industrial e financeiro). Vol.2. Rio de Janeiro: IBMEC, 1978.

LUCE, Mathias Seibel. Teoria Marxista da Dependência: categorias e problemas. Uma visão histórica. São Paulo: Editora Expressão Popular, 2018.

LUZ, Nicia Vilela. A Luta Pela Industrialização do Brasil: 1808 a 1930. Prefácio de João Cruz Costa. São Paulo: Alfa-Ômega, 1975, 2.ed.

MAESTRI, Mário. “O Escravismo Colonial: A revolução Copernicana de Jacob Gorender”. Revista Espaço Acadêmico. N.35 abr/2004. Disponível em: https://www.espacoacademico.com.br/035/35maestri.htm\# ftnref34;

MARINI, Ruy. Mauro. “Dialética da Dependência” In: STEDILE, J.P.; TRASPADINI, R. Ruy Mauro Marini: vida e obra. São Paulo: Editora Expressão Popular, 2005; 
MARTINS, José de Souza. 0 Cativeiro da Terra. São Paulo: Editora Contexto, 2010;

MARTINS, José de Souza. Conde de Matarazzo, o empresário e a empresa: estudo de sociologia do desenvolvimento. São Paulo: HUCITEC, 1976.

MARX, K. 0 Capital: crítica da economia política. Livro I: O processo de produção do capital. Trad. Rubens Enderle. São Paulo: Boitempo, 2013;

MARX, K. 0 Capital: crítica da economia política. Livro III: O processo global da produção capitalista. Trad. Rubens Enderle. São Paulo: Boitempo, 2017.

MELLO, 0 Capitalismo Tardio: contribuição à revisão crítica da formação e do desenvolvimento da economia brasileira. 8.ed. São Paulo: Editora Brasiliense, 1991.

RIBEIRO, Darcy. O Processo Civilizatório. Petrópolis: Editora Vozes, 1983. 7.ed.

SAES, Décio de Azevedo. A Formação do Estado Burguês no Brasil 1888-1891. Rio de Janeiro: Paz e Terra, 1990. 